\title{
Fluidodynamic analysis of cylindrical particles in fluidized bed with aspect ratio variation
}

\section{Análise fluidodinâmica de partículas cilíndricas em leito fluidizado com variação da razão de aspecto}

\author{
Dionisson de Andrade Michelotto ${ }^{1}$; Paulo Roberto Wander ${ }^{2}$
}

\begin{abstract}
The minimum fluid velocity of the particles is a hydrodynamic parameter that strongly influences the behavior in fluidized bed reactor designs. Most of the academic works use as one of the main parameters in their correlations the sphericity. Other studies state that the aspect ratio greatly influences the minimum fluidization velocity. Using a fluidized bed reactor, cylindrical bamboo particles with aspects ratios of 2, 4 and 6 were fluidized. The results of the minimum fluidization velocities were compared with other authors, where three were close enough within a range of variation of $20 \%$ of the values obtained in the experiments. A new correlation was proposed by varying the aspect ratio where the values of the minimum fluidization were very close to that of the experimental one.
\end{abstract}

Keywords: Fluidized bed. Aspect ratio. Minimum fluidization velocity.

\section{Resumo}

A velocidade mínima do fluido nas partículas é um parâmetro hidrodinâmico que influencia fortemente o comportamento em projetos de reatores de leito fluidizado. A maioria dos trabalhos acadêmicos utiliza como um dos principais parâmetros em suas correlações a esfericidade. Outros estudos afirmam que a razão de aspecto influencia grandemente a velocidade mínima de fluidização. Utilizando um reator de leito fluidizado, partículas de bambu cilíndricas com razões de aspecto de 2, 4 e 6 foram fluidizadas. Os resultados das velocidades mínimas de fluidização foram comparados com outros autores, onde três foram suficientemente próximos dentro de uma variação de $20 \%$ dos valores obtidos nos experimentos. Uma nova correlação foi proposta variando-se a razão de aspecto onde os valores da fluidização mínima foram muito próximos aos da experimental.

Palavras-chave: Leito fluidizado. Razão de aspecto. Velocidade mínima de fluidização.

\footnotetext{
${ }^{1}$ Me. Eng., UNISINOS, São Leopoldo, RS, Brasil; E-mail: dionisson.dam@gmail.com

2 Dr. Prof., Centro de Ciências Exatas e Tecnológicas, UNISINOS, São Leopoldo, RS, Brasil; E-mail: prwander@unisinos.br
} 


\section{Introduction}

Fluidized beds are found in many plant operations in the chemical, pharmaceutical and mineral industries (TAGHIPOUR; ELLIS; WONG, 2005). Fluidization bed technology is a method to achieve a higher combustion efficiency of 96-98\% and about 60-80 times higher rate of heat transfer in steam boilers than those obtained by submerging the heat exchanger in flue gases of fuels. It gives a boiler efficiency of $80-85 \%$ with additional advantage of low combustion temperature (800-900 C) and therefore low NOx emission (ABDULLAH, 2003).

The combustion zone in fluidized bed boilers operates under special hydrodynamic conditions essential for a good combustion process (ABDULLAH, 2003). The minimum fluid velocity of the particles is a hydrodynamic parameter that strongly influences the behavior of the fluidized beds. Therefore, its precise forecasting is of great importance for the design of such equipment (REINA; VELO; PUIGJANER, 2000; COLTTERS; RIVAS, 2004).

Much of the development of fluidized bed reactors has been empirical, since the complex behavior of the gas flow in the systems, makes flow modeling a challenging task (TAGHIPOUR; ELLIS; WONG, 2005).

The minimum fluid velocity of the particles is a hydrodynamic parameter that strongly influences the behavior of the fluidized beds. Therefore, its precise forecasting is of great importance for the design of such equipment (REINA; VELO; PUIGJANER, 2000; COLTTERS; RIVAS, 2004).

Much of the development of fluidized bed reactors has been empirical, since the complex behavior of the gas flow in the systems, makes flow modeling a challenging task (TAGHIPOUR; ELLIS; WONG, 2005). Many authors use the sphericity as the main parameter to elaborate their correlations, although Perez (2016) studied particles with a high aspect ratio, that is, with a length much larger than the diameter, which presented a high cohesiveness, making it practically impossible to fluidize them. It was also verified the formation of preferential channels, through which the gas escaped without being able to fluidize the bed.

There are few studies of the aspect ratio influence in the minimum fluidization velocity and so, this work demonstrates a new correlation of the variation of the minimum fluidization velocity with influence of the aspect ratio increase.

\section{Materials and Methods}

\section{Materials used}

For the analysis of the behavior of the influence of the aspect ratio of the particles were used standardized particles of woods of uniform shape and size, presented in Table 1.

Table 1 - Standard particle size and shape

\begin{tabular}{ccc}
\hline Format & $d(\mathrm{~mm})$ & $l(\mathrm{~mm})$ \\
\hline cylindrical & 2.00 & 4.00 \\
& 2.00 & 4.00 \\
& 2.00 & 12.00
\end{tabular}

Source: The authors.

\section{Determination of densities}

For the determination of the actual density of the components, a Quantachrome branded helium pycnometer, model AccuPyc II 1340 was used with an accuracy of $\pm 0.02 \%$ and accuracy of $0.03 \%$ in reading, in addition to $0.03 \%$ of the sample capacity, it was able to do ten repetitions in the sample measurements resulting in the mean value. In helium gas pycnometry this is introduced into the material samples, thus filling the voids and providing the actual value of the specific mass of each material. Three samples were separated into a $10 \mathrm{~mL}$ beaker that were placed on a pycnometer. To obtain the apparent specific mass of each material, its mass will be measured and placed in the bed an amount sufficient to maintain the ratio $H / D=1$. To determine the apparent specific mass the total mass added in the bed will be divided, occupied volume. The method was repeated three times for each of the components.

\section{Determination of sphericity and the aspect ratio}

Obtaining the three-dimensional images, through the analysis and digital treatment by the image J software, where it was possible to obtain the dimensions to determine the sphericity and the average aspect ratio for $4 \times 2$ $\mathrm{mm}$ and $8 \times 2 \mathrm{~mm}$ sticks. As it was not possible to place the particles of $12 \times 2 \mathrm{~mm}$ in the three-dimensional because the size exceeds that of the capturing capacity, a pachymeter was used to carry out the measurements and soon the data were processed. The dimensions of 50 samples were collected and its results are shown in Table 2.

Observing the results in Table 2, it was seen that the results presented a small difference from the values predicted in Table 1. 
Table 2 - Result of sphericity, aspect ratio

\begin{tabular}{cccc}
\hline \multicolumn{4}{c}{ Bamboo stick - 4x2mm } \\
\hline \multirow{4}{*}{$\begin{array}{c}\text { average } \\
\text { standard deviation }\end{array}$} & 0.155 & 0.239 & 0.024 \\
\cline { 2 - 4 } & Bamboo stick $-8 \times 2 \mathrm{~mm}$ & Ratio $l / b[-]$ & sphericity [-] \\
\hline \multirow{4}{*}{ average } & $d(\mathrm{~mm})$ & Ratio $l / b[-]$ & sphericity [-] \\
\cline { 2 - 4 } standard deviation & 2.050 & 4.208 & 0.744 \\
& 0.093 & 0.266 & 0.018 \\
\hline \multirow{4}{*}{ Bamboo stick $-12 \times 2 \mathrm{~mm}$} & \\
\hline \multirow{4}{*}{ average } & $d(\mathrm{~mm})$ & Ratio $l / b[-]$ & sphericity $[-]$ \\
\cline { 2 - 4 } standard deviation & 0.163 & 0.648 & 0.656 \\
\hline
\end{tabular}

Source: The authors.

\section{Experimental procedure}

The equipment used in this work is the same one used by Genehr (2015), being composed by a cylindrical tube of acrylic with internal diameter of $94 \mathrm{~mm}$ (4). The lower part of the bed, called the distributor, consists of a cylindrical stainless steel tube with a length of $100 \mathrm{~mm}$ (6). Below this cylinder has a half-cone (8) through which the air is blown for fluidization. Metal screens are installed on the lower (7) and upper (5) ends of the distributor. The screen at position 05 in Figure 1 serves to support the material added in the bed.

The distributors pressure drop was analyzed by increasing the flow rate to obtain their characteristic curves, according to Figure 2.

The data collected to obtain the curves were done in triplicate, but used in the same graph to obtain a trend line and its more precise polynomial equation for characteristic curve. Thus, the data treatment to obtain the fluid dynamic behavior in the bed must subtract the pressure drop of the distributor for each speed in the reactor using equation (1) for the fluidization result with the distributor

$$
\Delta p=\Delta p_{c o l}-\left(1.2205 u^{2}-0.772 u\right),
$$

where $\Delta p$ is the bed load loss, $\Delta p$ col is the bed load loss plus the distributor bed and $u$ is the bed surface velocity. To initiate the fluidization of the particles, each component was introduced through the top of the column until it reached a static height in the bed of $95 \mathrm{~mm}$ as can be seen in Figure 3.
Figure 1 - Bench fluidization equipment

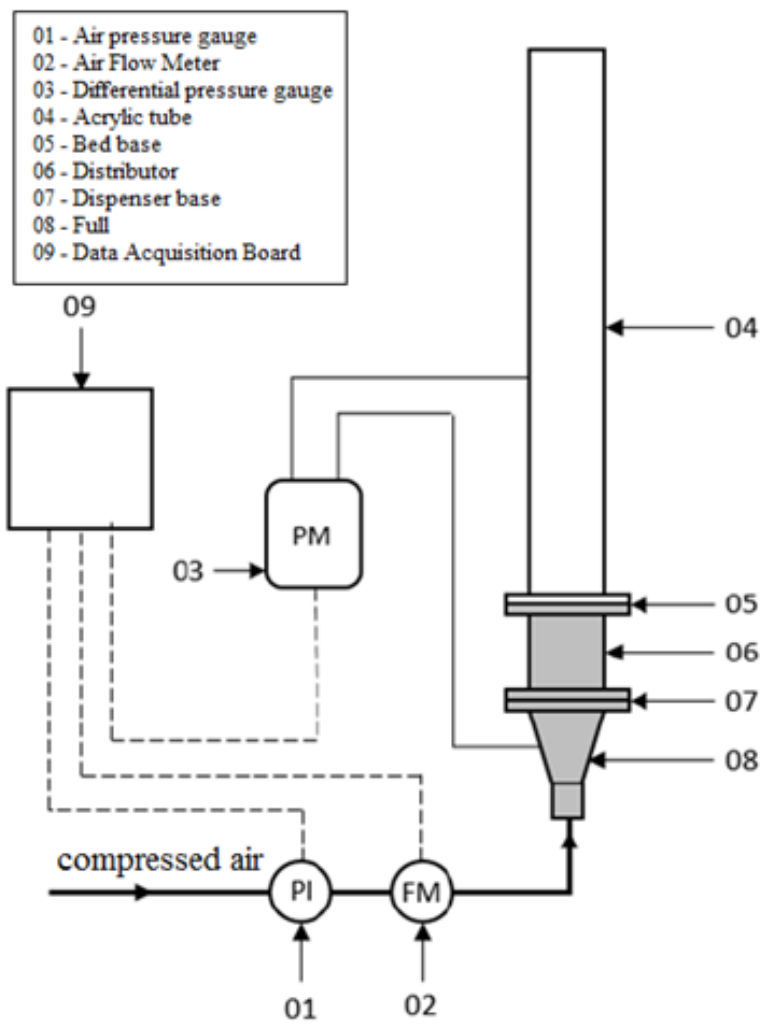

Source: Genehr, (2015).

As the bed of each component has not undergone any fluidization this type of bed is considered compacted. After the first fluidization, with the static bed, the bed is expanded in relation to the initial (compacted) static bed. This is called a bed with loose particles. For data collection of surface velocity and pressure loss in the bed, air was injected, gradually controlling the inlet flow through the 
Figure 2 - Characteristic curve of the pressure drop in the distributor

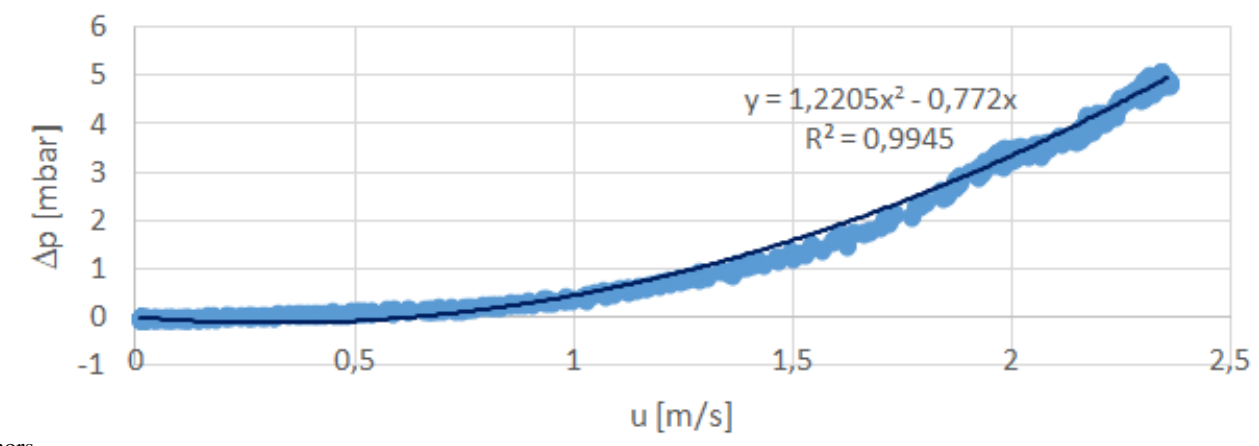

Source: The authors.

$$
\mathrm{u}[\mathrm{m} / \mathrm{s}]
$$

Figure 3 - Initial bed height (compacted) of particles with aspects ratios of 2, 4 and 6, in Figures 3.1-3.3, respectively.

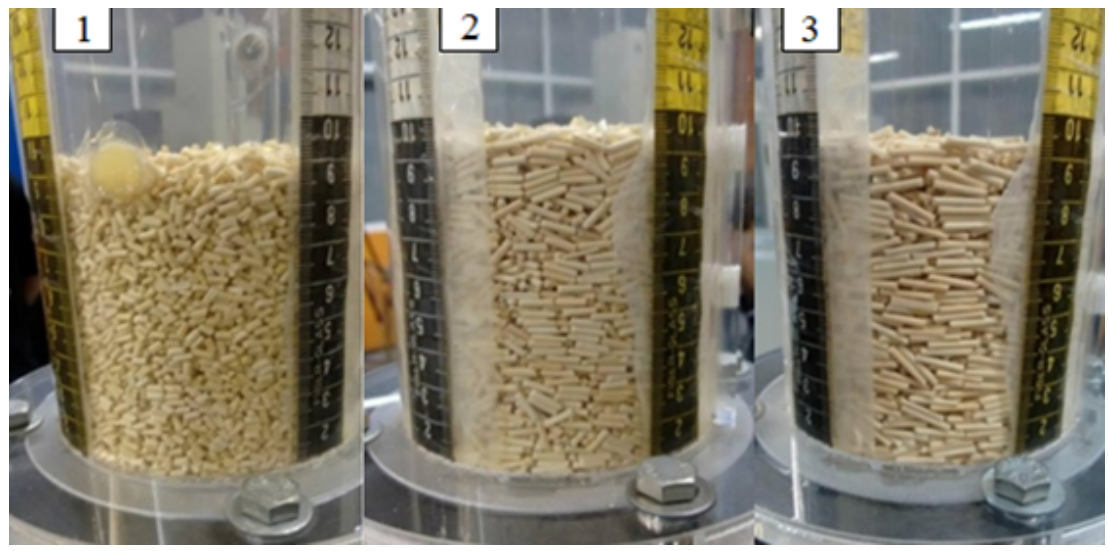

Source: The authors.

valve, where a velocity value corresponds to each opening interval. The pressure drop data was measured using a NOVUS instrument, model HUBA 699, with adjustable measuring range from 0 to $16 \mathrm{mbar}, 0$ to $25 \mathrm{mbar}$ and 0 to 50 mbar. Airflow values in the bed were measured using an IFM, model SD6050 flowmeter, which has a measurement range of 0.2 to $75 \mathrm{Nm}^{3} / \mathrm{h}$ with an accuracy of $\pm 1.5 \%$ and an analog signal output of 4 at $20 \mathrm{~mA}$. Pressure and flow data were collected through a NOVUS brand data plate, Fieldlogger model. It collected the data at the same time, allowing analysis of the behavior of pressure loss with variation of airflow in the bed. For each component the experiment was repeated three times considering the average of the values obtained.

\section{Results and Analysis}

\section{Fluid dynamics analysis}

The distributor used has holes concentrated in the central area, with some peripheral holes along the radius, but not close to the walls. It has a diameter of $94 \mathrm{~mm}$ and 45 holes with a diameter of $4 \mathrm{~mm}$ each, see Figure 4.

In Figures 5-7, it is possible to observe the compact fluidization (F COMP.), Loose fluidization (F SOLTA)
Figure 4 - Distributor (45 holes of 4mm).

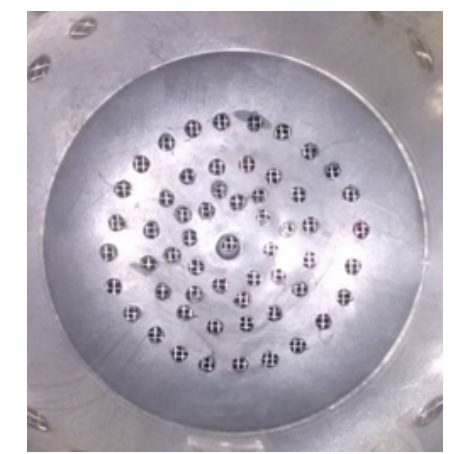

Source: The authors.

and defluidization (D) of the $4 \times 2 \mathrm{~mm}, 8 \times 2 \mathrm{~mm}$ and $12 \times 2$ $\mathrm{mm}$ particles, and their minimum fluidization velocities, Table 3. Three distributors were studied. The distributor with a single hole in the center of the bed didn't fluidized creating preferential paths in the center. Other distributor with holes distributed all over the area generated a piston effect.

Table 3 - Results of minimum fluidization.

\begin{tabular}{cccc}
\hline Bamboo stick & $4 \times 2 \mathrm{~mm}$ & $8 \times 2 \mathrm{~mm}$ & $12 \times 2 \mathrm{~mm}$ \\
\hline $\begin{array}{c}u \mathrm{mf}[\mathrm{m} / \mathrm{s}] \\
\mathrm{c} / \text { distribuidor } 1\end{array}$ & 1.24 & 1.32 & 1.53 \\
\hline
\end{tabular}

Source: The authors. 
Figure 5 - Fluidization and defluidization of the $4 \times 2$ particles

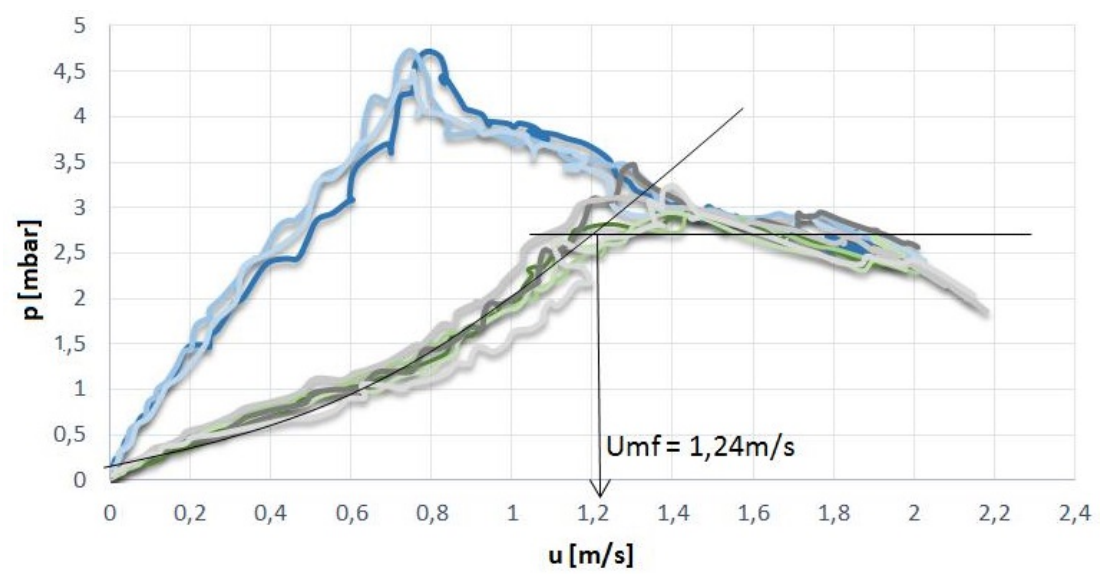

$$
\begin{array}{ll}
\text { F1 COMP. } & \text { F2 COMP. } \\
\text { D1 } & \text { F3 COMP. } \\
\text { D1 SOLTA } & \text { F2 SOLTA }
\end{array}
$$

Source: The authors.

Figure 6 - Fluidization and defluidization of the $8 \times 2$ particles

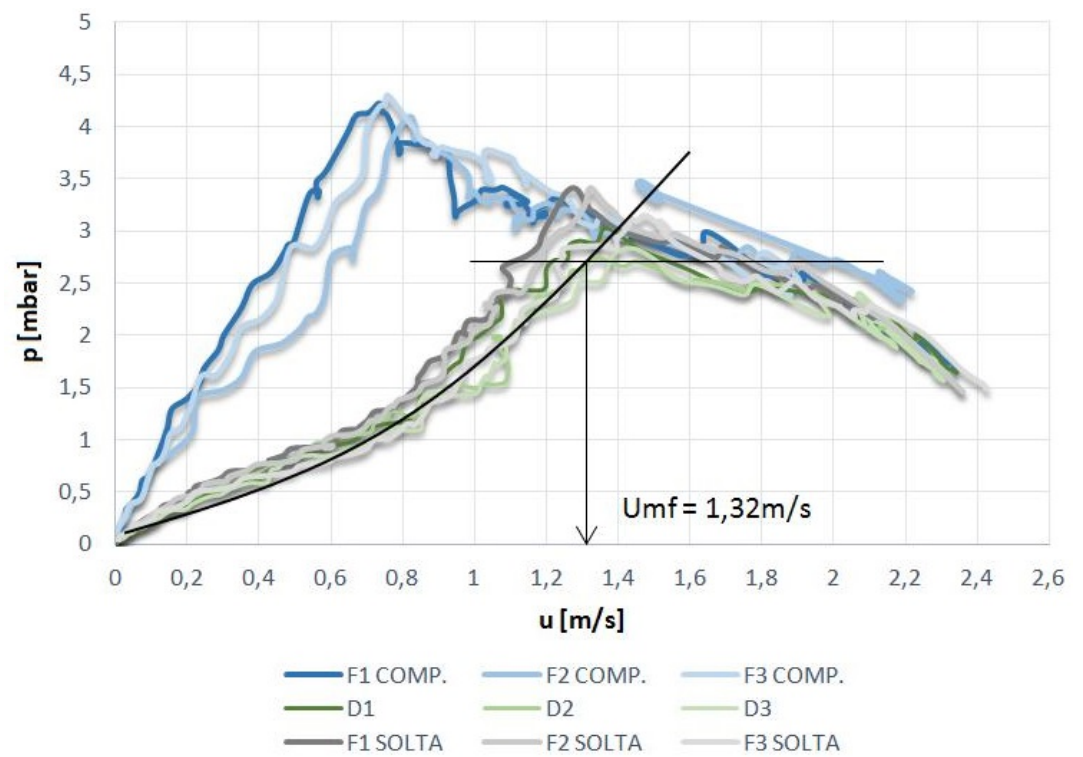

Source: The authors.

Figure 7 - Fluidization and defluidization of the $12 \times 2$ particles

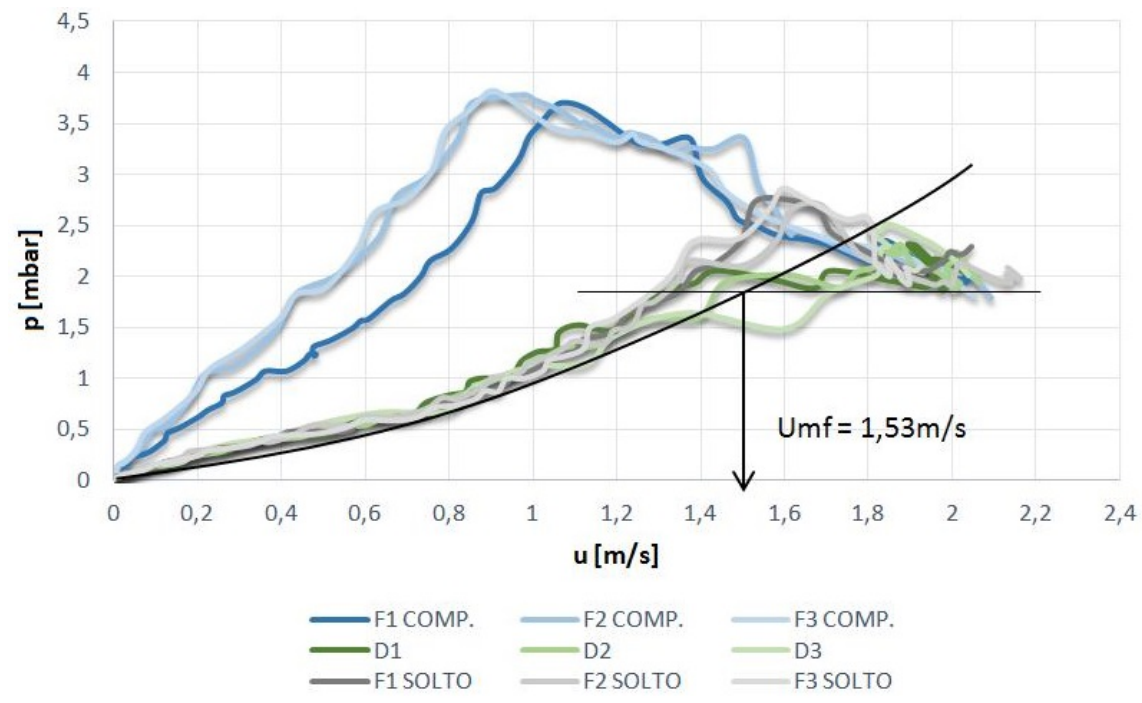

Source: The authors. 
Figure 8 - Expansion of the bed after fluidization of the particles of $4 \times 2 \mathrm{~mm}, 8 \times 2 \mathrm{~mm}$ and 12x2mm, in Figures 8.1-8.3, respectively.
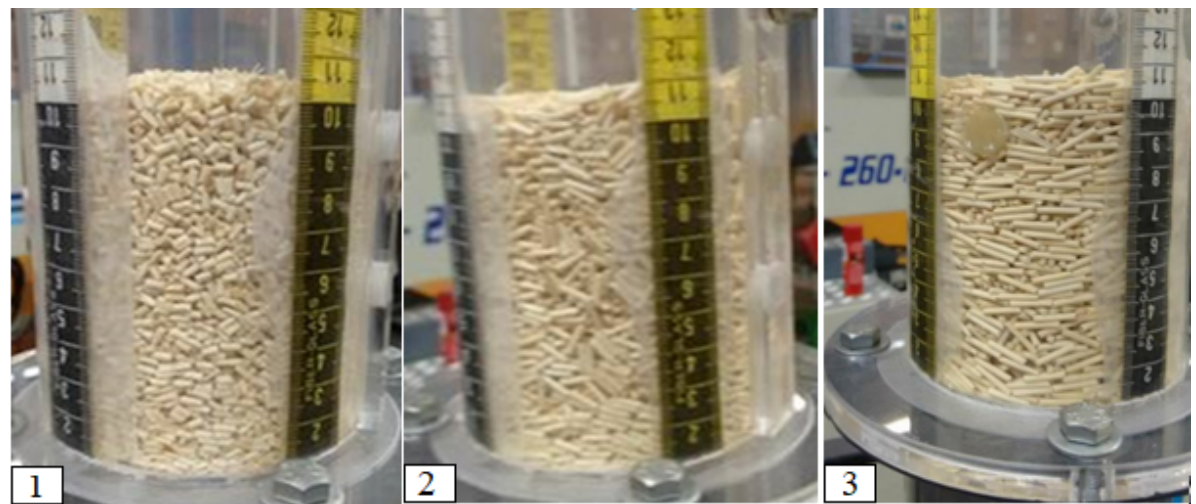

Source: The authors.

\section{Expansion of the static bed after fluidization}

After the first fluidization, it was verified the expansion of the bed at the end of the defluidization of the particles of $4 \times 2 \mathrm{~mm}, 8 \times 2 \mathrm{~mm}$ and $12 \times 2 \mathrm{~mm}$, which they can be observed in Figure 8.

Comparing Figure 3 with the images of the compacted fixed bed of Figure 8, the difference in bed expansion was obtained, where the results are shown in Table 4.

Table 4 - Difference of the static heights of the beds

\begin{tabular}{lccc}
\hline Bamboo stick & $4 \times 2 \mathrm{~mm}$ & $8 \times 2 \mathrm{~mm}$ & $12 \times 2 \mathrm{~mm}$ \\
\hline $\begin{array}{l}\text { Static bed height } \\
\text { compacted }\end{array}$ & 95 & 97 & 95 \\
Static bed height loose & 105 & 109 & 109 \\
Difference & 10 & 12 & 14 \\
\hline
\end{tabular}

Source: The authors.

\section{Proposal of a new correlation}

With the analysis of the experimental results it was possible to develop a new mathematical model for the determination of the (umf) of the particles of bamboo stick. This model was obtained by the logarithmic trend line, which allowed the determination of this parameter as a function of the particle diameter with a $R^{2}=0.9997$, and it is possible to develop the correlation equation (2)

$$
u_{m f}=1.1828-0.054 \ln \left(R A^{-1}-0.165\right) .
$$

\section{Comparison with Empirical Correlations for Minimum Fluidization Velocities}

The minimum velocities of fluidization Umf verified in the fluidization of toothpicks and presented Table 4 were compared with correlations of the authors of the bibliographic review. The results of these comparisons are expressed in Figure 9.

Figure 9 - Comparison of experimental and theoretical values for Umf

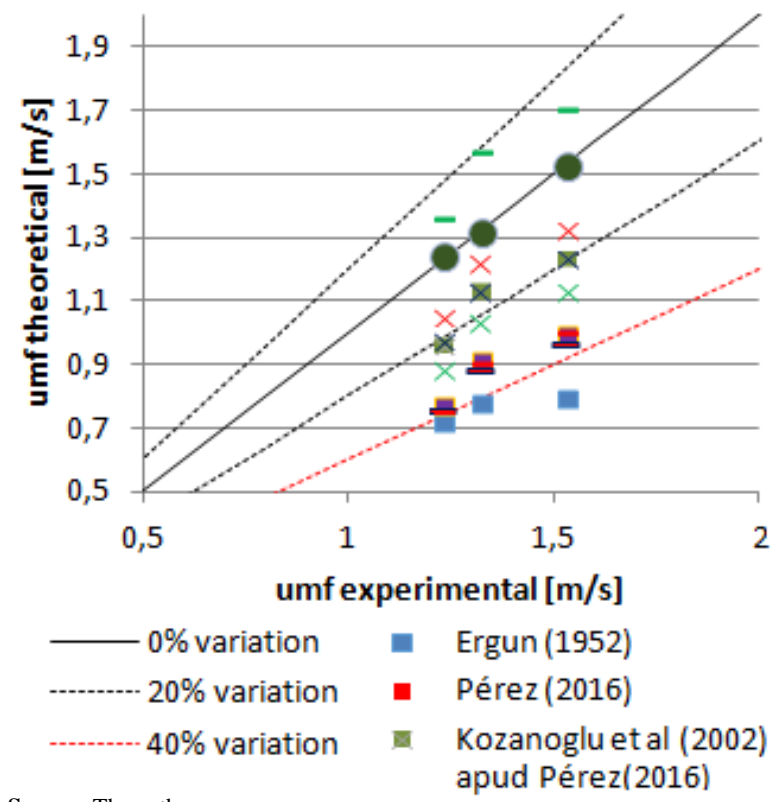

Source: The authors.

Analyzing the graph of Figure 9, it can be seen that the empirical correlations of the literature review that most approached the experimental one were Paudel and Feng (2013), Babu (1978) apud Pérez (2016), Chitester and kornodky (1984) apud Pérez (2016), Saxena and Vogel (1977) apud Pérez (2016) and Kozanoglu (2002) apud Pérez (2016) ranging from $20 \%$. The proposed model was just above the $0 \%$ variation line. It was also seen that the minimum fluidization velocity tends to increase with the increase of the aspect ratio and comparing with some authors it was possible to observe that in the correlations the minimum velocities remain close with the increase of the aspect ratio. 


\section{Conclusion}

It is possible to fluidize the laboratory-scale bamboo sticks in a cylindrical bed without damaging the essential structures of its shape using a distributor with peripheral holes instead of a single central hole for the spout. It was observed that without peripheral holes in the distributor, preferential paths were formed and most particles didn't return to the center of the bed. It's important that the distributor doesn't have holes near the walls of the reactor to avoid piston effect.

The higher the aspect ratio of the particle, the greater the variation in the static height of the compacted bed for the loose bed and consequently the greater the void fraction.

The empirical correlations of the bibliographic review that most approached the experimental one were those of Paudel and Feng (2013), Babu (1978) apud Pérez (2016), Chitester and kornodky (1984) apud Pérez (2016), Saxena and Vogel (1977) apud Pérez (2016) and Kozanoglu (2002) apud Pérez (2016) ranging from $20 \%$. The proposed model was just above the $0 \%$ variation line.

\section{References}

ABDULLAH, M.Z.; HUSAIN, Z.; YIN PONG, S.L. Analysis of cold flow fluidization test results for various biomass fuels. Biomass and Bioenergy, Amsterdam, v. 24, p. 487-494, 2003.

COLTTERS, R.; RIVAS, A.L. Minimum fluidation velocity correlations in particulate systems. Powder Technology, Caracas, v.147 p. 34-48, 2004.
GENEHR, G. A. Caracterização da fluidização de biomassas de cascas de madeiras em leitos polidispersos. 2015. 94 f. Dissertação (Mestrado em Engenharia Mecânica) Programa de Pós-Graduação em Engenharia Mecânica, Universidade do Vale do Rio dos Sinos (UNISINOS), 2015.

PAUDEL, B.; FENG, Z.-G. Prediction of minimum fluidization velocity for binary mixtures of biomass and inert particles. Powder Technology, Amsterdam, v. 237, p. 134140,2013

PÉREZ, Nestor Proenza et al. Comportamento fluidodinâmico de partículas de bagaço de cana-de-açúcar. In: CONGRESSO NACIONAL DE ENGENHARIA MECÂNICA - CONEM, 9., 2016, Fortaleza, Anais [...]. Fortaleza, 2016.

REINA, J.; VELO, E.; PUIGJANER, L. Predicting the minimum fluidization velocity of polydisperse mixtures of scrap-wood particles. Powder Technology, v. 111, p. 245-251, 2000.

TAGHIPOUR, F.; ELLIS, N.; WONG, C.; Experimental and computational study of gas-solid fluidized bed hydrodynamics. Chemical Engineering Science, p. 6857-6867, 2005. 
